\title{
Reduced sulphation factor in undernourished children
}

\author{
D. B. GRANT, JUDY HAMBLEY, DOROTHY BECKER, „ and B. L. PIMSTONE^ \\ From the Clinical Research Centre, Harrow, Middlesex, and the Departments of Medicine and Child Health, University \\ of Cape Town Medical School, South Africa
}

\begin{abstract}
Grant, D. B., Hambley, J., Becker, D., and Pimstone, B. L. (1973). Archives of Disease in Childhood, 48, 596. Reduced sulphation factor in undernourished children. Serum sulphation factor (SF) activity was estimated in serial samples from 5 children with protein-calorie malnutrition. Serum growth hormone (HGH), albumin, and transferrin were also measured. SF activity was reduced at the time of admission, but had risen in all patients by the ninth day of treatment. While serum HGH fell during treatment, there was no obvious relation between the changes in SF and $\mathrm{HGH}$ in each patient. Serum albumin rose during treatment and showed a correlation with the changes in serum SF. The pattern of recovery in serum transferrin was also similar to that shown by SF.
\end{abstract}

In 1957, Salmon and Daughaday reported that serum from normal rats stimulated the in vitro incorporation of ${ }^{35} \mathrm{~S}$ into costal cartilage from hypophysectomized rats. This serum sulphation factor (SF) activity was reduced in hypophysectomized rats but could be restored by growth hormone injections. Daughaday, Salmon, and Alexander (1959) subsequently showed that human serum also had growth hormone-dependent SF activity, a finding which was soon confirmed by others, and it has been suggested that the growth-promoting effects of HGH may be mediated by SF (Daughaday, 1971).

In the rat SF levels are reduced during starvation (Daughaday and Kipnis, 1966), indicating that factors other than growth hormone secretion may modify serum SF activity. This paper describes results obtained in 5 children with protein-calorie

Abbreviations
SF: sulphation factor
HGH: human growth hormone
PCM: protein-calorie malnutrition
HEPES: N-2-hydroxyethylpiperazine-N-2-
ethanesulphonic acid
PPO: 2,5-diphenyloxazole
POPOP: p-Bis (2-(5-phenyloxazolyl)-
benzene

Received 12 January 1973.

^Present address : University of Cape Town Medical School, Cape Town, South Africa. malnutrition (PCM) which indicate that SF activity may also be reduced by severe malnutrition in man.

\section{Patients and methods}

Patients. 3 boys and 2 girls, aged 11 months to 2 years 8 months, were admitted to the metabolism ward of the Red Cross Children's Hospital, Cape Town, suffering from PCM. All the children were underweight with hypoalbuminaemia and oedema. Treatment in hospital consisted of protein supplements, intravenous fluids where necessary, antibiotics as indicated, potassium chloride, and vitamin supplements.

Methods. On the day after admission, blood was taken by venepuncture after an overnight fast, immediately before starting protein supplementation. Further fasting specimens were taken 5,9 , and 22 to 30 days after starting treatment. The last samples were obtained before discharge, at a stage of clinical and biochemical recovery. Serum specimens were stored frozen until used.

Serum SF activity was estimated using a modification of the method described by Hall (1970). Pelvic rudiments from 11-day chicks were added in random order to glass vials containing $0.95 \mathrm{ml}$ dilute serum. Three pelvic cartilages were added to each vial and observations were made in duplicate, giving 6 cartilages for each serum concentration. $50 \mathrm{mmol} / 1$. HEPES $(p \mathrm{H}$ $7 \cdot 4)$ was used as diluent. The incubation medium contained penicillin $(100 \mu \mathrm{m} / \mathrm{ml})$ and streptomycin $(100$ $\mu \mathrm{g} / \mathrm{ml}$ ) in addition to salts, amino acids, and glucose at the concentrations used by Hall (1970). After 60 minutes' preincubation at $37{ }^{\circ} \mathrm{C}, 0.05 \mathrm{ml}$ diluent containing approximately $1 \mu \mathrm{Ci}^{35} \mathrm{~S}$ was added to each vial and incubation continued for a further 18 hours. The cartilages were then placed in saturated $\mathrm{Na}_{2} \mathrm{SO}_{4}$ for 
24 hours before being washed thoroughly, dried at room temperature, and weighed. Individual cartilages were digested overnight with $1.0 \mathrm{ml} 0.05 \mathrm{~mol} / 1 . \mathrm{NaH}_{2} \mathrm{PO}_{4}$ containing papain $(1 \mathrm{mg})$, cysteine $(2 \mathrm{mg})$, and EDTA ( $2 \mathrm{mg}$ ), followed by the addition of $0.1 \mathrm{ml} \mathrm{N} \mathrm{NaOH}$ and further incubation at $60^{\circ} \mathrm{C}$ for 1 hour. Samples were counted in $15 \mathrm{ml} 3: 1 \mathrm{v} / \mathrm{v}$ toluene : triton with PPO $(0.6 \mathrm{~g} / 100 \mathrm{ml})$ and dimethyl-POPOP $(0.02 \mathrm{~g} / 100 \mathrm{ml})$. The channels ratio method was used to check for quenching, and results were expressed as ${ }^{35} \mathrm{~S}$ counts/min per mg cartilage.

In each experiment cartilages were incubated with $5 \%$ and $20 \%$ serum and all four samples from any one patient were compared with a pooled reference serum from two healthy men. Results were analysed using methods described by Finney (1964) to compare the dose-response slopes given by different specimens and to estimate SF potency relative to the reference serum. As early samples from 2 patients consistently gave responses which were not parallel to the control serum, it was not possible to ascribe numerical SF values to all the samples.

Serum HGH was estimated by a double antibody radioimmunoassay (Morgan and Lazarow, 1963) using HGH obtained from the National Institutes of Health (H S1394) for iodination and as a standard.

Serum albumin was estimated by the biuret method
(Wolfson et al., 1948) and transferrin by the method of Mancini, Carbonara, and Heremans (1965).

Pooled within-patient correlation coefficients were calculated between mean ${ }^{35} \mathrm{~S}$ uptake in 5\% and $20 \%$ serum and $\mathrm{HGH}$, albumin, and transferrin levels. Two-way analysis of variance of SF activity with respect to time, patient-time interaction, and between-patient variation was also done. As the assay error appeared to be proportional to the serum SF activity, log. values for ${ }^{35} \mathrm{~S}$ incorporation were used for analysis of variance.

\section{Results}

Sulphation factor. Results for ${ }^{35} \mathrm{~S}$ incorporation are given in Table I. The values obtained with four specimens from each patient are compared with the results for the control serum in each experiment.

In all 5 patients serum SF activity increased during treatment. In 3 patients a rise was detected 5 days after admission to hospital, and by the ninth day all the patients showed increased serum SF activity. SF results for specimens of serum taken before discharge from hospital were also higher than those obtained for the pretreatment samples.

TABLE I

Serum SF, HGH, albumin, and transferrin results in serial samples obtained from 5 children during treatment for PCM

\begin{tabular}{|c|c|c|c|c|c|c|}
\hline \multirow{2}{*}{$\begin{array}{c}\text { Case } \\
\text { no. }\end{array}$} & \multirow[t]{2}{*}{$\begin{array}{l}\text { Day of } \\
\text { sample }\end{array}$} & \multicolumn{2}{|c|}{$\begin{array}{c}{ }^{35} \mathrm{~S} \text { incorporation } \pm S E M \\
\left(10^{3} \text { counts/min per } \mathrm{mg} \text { cartilage) }\right.\end{array}$} & \multirow{2}{*}{$\begin{array}{l}\text { Serum } \\
\text { HGH } \\
(\mathbf{n g} / \mathbf{m l})\end{array}$} & \multirow{2}{*}{$\begin{array}{c}\text { Serum } \\
\text { albumin } \\
(\mathrm{g} / 100 \mathrm{ml})\end{array}$} & \multirow{2}{*}{$\begin{array}{l}\text { Serum } \\
\text { transferrin } \\
(\mathrm{mg} / \mathrm{ml})\end{array}$} \\
\hline & & $5 \%$ serum & $20 \%$ serum & & & \\
\hline Control serum & $\begin{array}{r}1 \\
5 \\
9 \\
27\end{array}$ & $\begin{array}{rr}4 \cdot 1 & (0 \cdot 2) \\
4 \cdot 5 & (0 \cdot 7) \\
67 \cdot 6 & (4 \cdot 9) \\
76 \cdot 4 & (8 \cdot 6) \\
96 \cdot 5 & (5 \cdot 8)\end{array}$ & $\begin{array}{r}48 \cdot 0(8 \cdot 0) \\
38 \cdot 9(3 \cdot 7) \\
94 \cdot 1 \quad(4 \cdot 1) \\
118 \cdot 8(10 \cdot 1) \\
163 \cdot 6(6 \cdot 4)\end{array}$ & $\begin{array}{r}13 \cdot 5 \\
16 \cdot 0 \\
6 \cdot 7 \\
1 \cdot 9 \\
-\end{array}$ & $\begin{array}{l}1.5 \\
1.4 \\
1.8 \\
3.9 \\
-\end{array}$ & $\begin{array}{l}1 \cdot 6 \\
1 \cdot 1 \\
2 \cdot 3 \\
5 \cdot 6 \\
-\end{array}$ \\
\hline Control serum & $\begin{array}{r}1 \\
5 \\
9 \\
26\end{array}$ & $\begin{array}{rr}5 \cdot 8 & (3 \cdot 2) \\
7 \cdot 0 & (1 \cdot 3) \\
28 \cdot 8 & (3 \cdot 3) \\
44 \cdot 7 & (10 \cdot 2) \\
79 \cdot 7 & (7 \cdot 3)\end{array}$ & $\begin{array}{rr}46 \cdot 7 & (3 \cdot 2) \\
51 \cdot 3 & (2 \cdot 6) \\
75 \cdot 4 & (5 \cdot 4) \\
127 \cdot 2 & (9 \cdot 3) \\
143 \cdot 3 & (6 \cdot 1)\end{array}$ & $\begin{array}{l}6 \cdot 9 \\
4 \cdot 6 \\
1 \cdot 5 \\
2 \cdot 8 \\
-\end{array}$ & $\begin{array}{l}1 \cdot 9 \\
2 \cdot 2 \\
2 \cdot 3 \\
3 \cdot 9 \\
-\end{array}$ & $\begin{array}{l}1 \cdot 3 \\
1 \cdot 3 \\
1 \cdot 7 \\
2 \cdot 9 \\
-\end{array}$ \\
\hline Control serum & $\begin{array}{r}1 \\
5 \\
9 \\
26\end{array}$ & $\begin{array}{ll}28 \cdot 6 & (1 \cdot 9) \\
47 \cdot 5 & (3 \cdot 4) \\
57 \cdot 1 & (2 \cdot 4) \\
68 \cdot 3 & (4 \cdot 3) \\
74 \cdot 6 & (4 \cdot 3)\end{array}$ & $\begin{array}{r}57 \cdot 5(6 \cdot 4) \\
74 \cdot 1 \quad(3 \cdot 0) \\
66 \cdot 0(8 \cdot 3) \\
92 \cdot 9(4 \cdot 4) \\
105 \cdot 3(11 \cdot 6)\end{array}$ & $\begin{array}{l}3 \cdot 2 \\
2 \cdot 3 \\
2 \cdot 3 \\
0 \cdot 7 \\
-\end{array}$ & $\begin{array}{l}2 \cdot 2 \\
2 \cdot 9 \\
3 \cdot 3 \\
4 \cdot 4 \\
-\end{array}$ & $\begin{array}{l}0 \cdot 9 \\
1 \cdot 7 \\
2 \cdot 3 \\
2 \cdot 9 \\
-\end{array}$ \\
\hline Control serum & $\begin{array}{r}1 \\
5 \\
9 \\
22\end{array}$ & $\begin{aligned} 4 \cdot 1 & (0 \cdot 6) \\
22 \cdot 7 & (6 \cdot 1) \\
39 \cdot 6 & (2 \cdot 0) \\
19 \cdot 1 & (6 \cdot 8) \\
44 \cdot 6 & (7 \cdot 8)\end{aligned}$ & $\begin{array}{ll}43 \cdot 0 & (2 \cdot 1) \\
76 \cdot 5 & (3 \cdot 9) \\
69 \cdot 3 & (4 \cdot 6) \\
61 \cdot 1 & (5 \cdot 2) \\
92 \cdot 8 & (8 \cdot 2)\end{array}$ & $\begin{array}{r}45 \cdot 5 \\
2 \cdot 5 \\
3 \cdot 5 \\
3 \cdot 2 \\
-\end{array}$ & $\begin{array}{l}2 \cdot 3 \\
2 \cdot 5 \\
3 \cdot 4 \\
3 \cdot 9 \\
-\end{array}$ & $\begin{array}{l}1 \cdot 3 \\
1 \cdot 7 \\
2 \cdot 6 \\
1 \cdot 6 \\
-\end{array}$ \\
\hline Control serum & $\begin{array}{r}1 \\
5 \\
9 \\
30\end{array}$ & $\begin{array}{ll}11 \cdot 0 & (1 \cdot 0) \\
11 \cdot 3 & (0 \cdot 7) \\
22 \cdot 8 & (1 \cdot 0) \\
24 \cdot 1 & (4 \cdot 9) \\
40 \cdot 1 & (2 \cdot 8)\end{array}$ & $\begin{array}{ll}30 \cdot 0 & (2 \cdot 0) \\
44 \cdot 1 & (1 \cdot 9) \\
57 \cdot 3 & (4 \cdot 3) \\
58 \cdot 5 & (3 \cdot 2) \\
63 \cdot 8 & (4 \cdot 3)\end{array}$ & $\begin{array}{r}9 \cdot 6 \\
7 \cdot 3 \\
13 \cdot 1 \\
7 \cdot 1 \\
-\end{array}$ & $\begin{array}{l}2 \cdot 4 \\
2 \cdot 9 \\
3 \cdot 0 \\
3 \cdot 5 \\
-\end{array}$ & $\begin{array}{l}2 \cdot 3 \\
2 \cdot 1 \\
5 \cdot 0 \\
3 \cdot 8 \\
-\end{array}$ \\
\hline
\end{tabular}

Note: SF results are given as ${ }^{35}$ S incorporation in $5 \%$ and $20 \%$ serum. 
In all patients ${ }^{35} \mathrm{~S}$ incorporation with the final samples was less than that given by the control serum. The dose responses of these final samples were parallel to the control serum, and estimates of their potencies gave values between 0.40 and 0.68 of the pooled adult specimen.

Two-way analysis of variance of the log. values for ${ }^{35} \mathrm{~S}$ incorporation (Table II) confirmed that within the group of patients there was a significant change in SF activity with time. The pattern of recovery of serum $S F$ varied in different patients, and smaller but significant $F$ values for patient-time interaction were also obtained. The high $F$ values obtained for between-patient variation were probably due to the design of the study, in which specimens from different patients were investigated in separate experiments.

\section{TABLE II}

Two-way analysis of variance of log. values for ${ }^{35} \mathrm{~S}$ incorporation with respect to time, patient-time interaction, and between-patient variation

\begin{tabular}{|c|c|c|}
\hline \multirow{2}{*}{ Source } & \multicolumn{2}{|c|}{ SF activity } \\
\hline & $5 \%$ serum & $20 \%$ serum \\
\hline $\begin{array}{l}\text { Time } \\
\text { (dy 1-dy 22/30) } \\
\text { Patient-time } \\
\text { interaction } \\
\text { Between-patient } \\
\text { variation }\end{array}$ & $\begin{array}{l}F=57 \cdot 52^{\star} \\
F=5 \cdot 86^{\star} \\
F=20 \cdot 09^{\star}\end{array}$ & $\begin{array}{l}F=38 \cdot 56^{\star} \\
F=5 \cdot 70^{\star} \\
F=9 \cdot 55^{\star}(8,101) \\
(4,101)\end{array}$ \\
\hline
\end{tabular}

${ }^{\star} P<0.001$.

In Cases 1 and 2, the slopes of the dose responses given by the first two serum samples were not parallel to those given by the control serum. This finding was confirmed in repeat experiments, and it appeared that these early samples might have an inhibitory effect in the SF assay. To test this possibility, the control serum was studied in the presence of serum from Cases 1 and 2. The results, given in Table III, indicate that neither specimen produced significant inhibition of the activity of the control serum.
Serum HGH. The serum HGH results are also given in Table I. In Case 4 a very high $\mathrm{HGH}$ value was obtained on admission, and 3 other patients showed less conspicuous rise of serum HGH in the initial samples. In 3 of these cases the levels fell to normal during treatment. There was no significant correlation between the changes in serum $\mathrm{HGH}$ and ${ }^{35} \mathrm{~S}$ incorporation in either $5 \%$ or $20 \%$ serum $(r=-0.47$ and $-0.44, \mathrm{P}>0.05)$.

Serum albumin. Serum albumin levels rose during treatment in all the patients (Table I). The 2 patients who had the lowest serum albumin levels on admission to hospital (Cases 1 and 2) showed the slowest rise in both albumin and SF during treatment. Significant pooled correlation coefficients were obtained between serum albumin concentration and ${ }^{35} \mathrm{~S}$ uptake in $5 \%$ and $20 \%$ serum $(r=0.75$ and $0.80, P<0.01)$.

Serum transferrin. With the exception of Case 4, there was a marked rise in serum transferrin during treatment (Table I). In each patient the pattern of recovery in serum transferrin was similar to that shown by serum SF, and significant correlation coefficients were obtained between ${ }^{35} \mathrm{~S}$ incorporation in both $5 \%$ and $20 \%$ serum and serum transferrin concentration $(r=0.79$ and 0.78 , $\mathbf{P}<0 \cdot 01)$.

\section{Discussion}

The above results indicate that serum SF activity is reduced in patients with PCM but begins to rise soon after treatment is begun. Though the specimens obtained after 3 to 4 weeks' treatment still appeared to have lower SF activity than serum from healthy adults, relatively low SF levels have been reported in healthy young children (Almqvist and Rune, 1961; Kogut, Kaplan, and Shimizu, 1963), and the values in our cases may have been normal at the time of discharge from hospital.

We are uncertain as to the significance of discrepancies in the slopes of the dose response for pre- and post-treatment samples in 2 patients. Serum from fasted rats has been reported to contain

TABLE III

$S F$ results for adult control serum studied in the presence of early serum samples from Cases 1 and 2

\begin{tabular}{|c|c|c|c|c|}
\hline \multirow{2}{*}{$\begin{array}{l}\text { Case } \\
\text { no. }\end{array}$} & \multicolumn{4}{|c|}{${ }^{35} \mathrm{~S}$ incorporation $\pm \mathrm{SEM}\left(10^{3}\right.$ counts $/ \mathrm{min}$ per $\mathrm{mg}$ cartilage) } \\
\hline & No serum & $5 \%$ test serum & $5 \%$ control serum & $\begin{array}{c}5 \% \text { test serum } \\
+ \\
5 \% \text { control serum }\end{array}$ \\
\hline $\begin{array}{l}1 \\
2\end{array}$ & $\begin{array}{l}39 \cdot 6(3 \cdot 7) \\
26 \cdot 0(2 \cdot 6)\end{array}$ & $\begin{array}{l}34 \cdot 3(2 \cdot 6) \\
32 \cdot 8(1 \cdot 9)\end{array}$ & $\begin{array}{r}104 \cdot 5(6 \cdot 6) \\
77 \cdot 0(10 \cdot 8)\end{array}$ & $\begin{array}{l}99 \cdot 5(5 \cdot 1) \\
82 \cdot 7(7 \cdot 8)\end{array}$ \\
\hline
\end{tabular}


an inhibitor of ${ }^{35} \mathrm{~S}$ incorporation (Salmon, 1972), but we were unable to show similar inhibition with our specimens. Alternatively, as the log-dose response in our assay appears sigmoid in shape, the findings in these 2 patients may have been due to our failure to use a high enough concentration of pretreatment serum.

Low serum SF levels, which can be restored by HGH therapy, have been a common finding in patients with HGH deficiency (Daughaday et al., 1959; Almqvist, 1960; Hall and Olin, 1972), and it is widely accepted that $\mathrm{HGH}$ secretion plays an important role in controlling serum SF in man. However, the low SF activity in our patients was not due to $\mathrm{HGH}$ deficiency, as circulating $\mathrm{HGH}$ levels were raised in 4 patients before treatment. It therefore appears that serum SF is not solely dependent on HGH secretion. This association between high serum HGH and low serum SF is similar to the findings described by Laron et al. (1971) in children with apparent 'end-organ unresponsiveness' to HGH. Tanner (1972) has suggested that serum SF may inhibit HGH secretion and has postulated that Laron's patients have high serum HGH levels as a result of failure of the feedback mechanism. Though the slow recovery of SF and albumin in Case 1 paralleled the return of $\mathrm{HGH}$ levels to normal, a close correlation between SF and HGH was not found in the other patients, possibly since only single basal HGH estimations were obtained.

The wide range of metabolic abnormalities found in patients with PCM have been recently reviewed by Whitehead and Alleyne (1972) and Pimstone, Becker, and Hansen (1972). In addition to marked changes in body water, potassium, and magnesium, the plasma amino acid pattern is abnormal and plasma albumin, transferrin, and $\beta$-lipoprotein are reduced. Serum HGH values are raised and hypoglycaemia is common, despite raised plasma cortisol levels and a reduction in serum insulin. The present investigation does not permit detailed analysis of the relation between these abnormalities and serum SF activity. The results do, however, indicate that serum albumin, transferrin, and SF activity all show similar patterns of recovery in PCM. There is evidence that SF is a peptide which is synthesized by the liver (McConaghey and Sledge, 1970; Van den Brande et al., 1971) and the above findings may reflect an abnormality of protein synthesis by the liver in severe malnutrition. Alternatively, low SF levels may be more directly related to one or more of the metabolic and endocrine abnormalities found in PCM, and it is therefore possible that more careful studies on the relation between serum SF and other biochemical changes found in PCM might increase our understanding of the metabolism of SF in man. In particular, the relation between serum $S F$ and plasma amino acid concentration may be of interest.

It is still uncertain whether any of the biochemical changes found in PCM have an adaptive function, or whether they merely represent a general breakdown in homoeostatic mechanisms. Daughaday (1971) has argued that the effect of HGH on growth may be mediated through SF and has pointed out the advantage of a system which permits rapid changes in serum $\mathrm{HGH}$ to exert a sustained effect through an intermediary with a much longer half life. If the view that SF mediates the growthpromoting effect of $\mathrm{HGH}$ is correct, the low SF levels found in our patients could be advantageous, directing available resources away from long-term requirements, such as growth, and toward more urgent needs.

We thank Dr. K. McPherson for statistical help.

\section{REFERENCES}

Almqvist, S. (1960). Studies on sulfation factor (SF) activity of human serum. Effect of human growth hormone on SF levels in pituitary dwarfism. Acta Endocrinologica, 35, 381.

Almqvist, S., and Rune, I. (1961). Studies on sulfation factor (SF) activity of human serum. The variation of serum SF with age. Acta Endocrinologica, 36, 566.

Daughaday, W. H. (1971). Sulfation factor regulation of skeletal growth. A stable mechanism dependent on intermittent growth hormone secretion. American fournal of Medicine, 50, 277.

Daughaday, W. H., and Kipnis, D. M. (1966). The growthpromoting and anti-insulin actions of somatotropin. Recent Progress in Hormone Research, 22, 49.

Daughaday, W. H., Salmon, W. D., Jr., and Alexander, F. (1959). Sulfation factor activity of sera from patients with pituitary disorders. Fournal of Clinical Endocrinology, 19, 743.

Finney, D. J. (1964). Statistical Method in Biological Assay, 2nd ed. Griffin, London.

Hall, K. (1970). Quantitative determination of the sulphation factor activity in human serum. Acta Endocrinologica, 63, 338.

Hall, K., and Olin, P. (1972). Sulphation factor activities and growth rate during long-term treatment of patients with pituitary dwarfism with human growth hormone. Acta Endocrinologica, 69, 417.

Kogut, M. D., Kaplan, S. A., and Shimizu, C. S. N. (1963). Growth retardation: use of sulfation factor as a bioassay for growth hormone. Pediatrics, 31, 538 .

Laron, Z., Pertzelan, A., Karp, M., Kowadlo-Silbergeld, A., and Daughaday, W. H. (1971). Administration of growth hormone to patients with familial dwarfism with high plasma immunoreactive growth hormone: measurement of sulfation factor, metabolic and linear growth responses. Fournal of Clinical Endocrinology, 33, 332.

McConaghey, P., and Sledge, C. B. (1970). Production of 'sulphation factor' by the perfused liver. Nature (London), 225, 1249.

Mancini, G., Carbonara, A. O., and Heremans, J F. (1965). Immunochemical quantitation of antigens by single radial immunodiffusion. Immunochemistry, 2, 235.

Morgan, C. R., and Lazarow, A. (1963). Immunoassay of insulin: two antibody system. Diabetes, $12,115$.

Pimstone, B. L., Becker, D. J., and Hansen, J. D. L. (1972). Human growth hormone in protein-calorie malnutrition. In Growth and Growth Hormone, p. 389 . Ed. by A. Pecile and E. E. Müller. Excerpta Medica, Amsterdam. 
Salmon, W. D., Jr. (1972). Investigation with a partially purified preparation of serum sulfation factor: lack of specificity for cartilage sulfation. In Growth and Growth Hormone, p. 180. Ed. by A. Pecile and E. E. Müller. Excerpta Medica, Amsterdam.

Salmon, W. D., Jr., and Daughaday, W. H. (1957). A hormonally controlled serum factor which stimulates sulfate incorporation by cartilage in vitro. Fournal of Laboratory and Clinical Medicine, 49, 825 .

Tanner, J. M. (1972). Human growth hormone. Nature (London), 237, 433.

Van den Brande, J. L., Van Wyk, J. J., Weaver, R. P., and Mayberry, H. E. (1971). Partial characterization of sulfation and thymidine factors in acromegalic plasma. Acta Endocrinologica, 66, 65.
Whitehead, R. G., and Alleyne, G. A. O. (1972). Pathophysiological factors of importance in protein-calorie malnutrition. British Medical Bulletin, 28, 72.

Wolfson, W. Q., Cohn, C., Calvary, E., and Ichiba, F. (1948). Studies in serum proteins; a rapid procedure for the estimation of total protein, true albumin, total globulin, alpha globulin, beta globulin and gamma globulin in $1.0 \mathrm{ml}$ of serum. American fournal of Clinical Pathology, 18, 723.

Correspondence to Dr. D. B. Grant, Division of Infant Development, Clinical Research Centre, Watford Road, Harrow, Middlesex HA1 3UJ. 